\title{
04. II. Dünya Savaşı esnasında Amerikan askerlerine Türkçe öğretmek için yazılan "Turkish: A Guide To The Spoken Language" adlı kitabın dil öğretimi açısından değerlendirilmesi
}

Elif ERMAĞAN1

APA: Ermağan, E. (2021). II. Dünya Savaşı esnasında Amerikan askerlerine Türkçe öğretmek için yazılan "Turkish: A Guide To The Spoken Language" adlı kitabın dil öğretimi açısından değerlendirilmesi. RumeliDE Dil ve Edebiyat Araştırmaları Dergisi, (Ö9), 43-55. DOI: 10.29000/rumelide.983856.

\section{Öz}

Yabancı dil olarak Türkçe öğretiminde kullanılan materyallerin başında kitaplar gelmektedir. Hedef kitleye yönelik hazırlanmış kitap türlerinden biri de kendi kendine Türkçe öğrenimi kitaplarıdır. Bu kitapların oluşturulmasında, öğrenicilerin ana dili ölçüt olarak alınmakla birlikte çeşitli meslek gruplarına yönelik, hedeflenen beceriyi kazandırmak amacıyla yayımlanmış kitaplar da bulunmaktadır. Bu gruba dâhil edilebilecek kitaplardan biri de 1943 basıml, Amerikan askerlerine Türkçe öğretmek için yazılan "Turkish: A Guide to the Spoken Language” adlı eserdir. ABD’nin Savaş Bölümü’nün hazırladığı bu kitap ile kendi ordu personeline Türkçe öğretme hedefi güdülmüştür. Bu makalede, Amerikan askerlerine yönelik hazırlanan bu kitap dil öğretimi açısından incelenmiş ve bazı sonuçlar ortaya konulmuștur. Analiz edilen kitap; dil öğretim yöntemi, dil becerileri, dil bilgisi öğretimi, alıştırmalar, kültür aktarımı, görseller, amaç ve hedef kitle açısından değerlendirilmeye tabi tutulmuştur. Bu çalışmada nitel araştırma yaklaşımı benimsenerek veriler doküman incelemesi yoluyla toplanmış ve elde edilen veriler içerik analizi tekniğiyle incelenerek temalar belirlenmiştir. Araştırmanın bulgularında; işitsel-dilsel yöntemle yazılan bu kitapta, amaca uygun olarak konuşma becerisinin geliştirilmesine yönelik telaffuz alıştırmalarına ağırlık verildiği, kelime öğretiminin Türkçe-İngilizce karşılaştırmalı olarak aktarıldığı ve öğretilmesi planlanan kelime listesinin hedef kitleye yönelik seçilmeye çalışıldığı tespit edilmiştir.

Anahtar kelimeler: Konuşma Becerisi, İşitsel-Dilsel Yöntem, İkinci Dünya Savaşı

\section{Evaluation in terms of language teaching "Turkish: A Guide to the Spoken Language", a book written to teach Turkish to American soldiers during The II. World War}

\begin{abstract}
Books come first among the materials used in teaching Turkish as a foreign language. One of the types of books prepared for the target audience is self-learning Turkish books. While the mother tongue of the learners is taken as a criterion in the creation of these books, there are also books published for various occupational groups in order to gain the targeted skills. One of the books that can be included in this group is "Turkish: A Guide to the Spoken Language", published in 1943, which was written to teach Turkish to American soldiers. With this book prepared by the US War Department, it is aimed to teach Turkish to its own army personnel. In this article, this book prepared for American soldiers is examined in terms of language teaching and some results are presented. The analyzed book; is evaluated in terms of language teaching methods, language skills, grammar teaching, exercises, cultural transfer, visuals, purpose and target audience. In this study, by adopting a qualitative research approach, the data were
\end{abstract}

Dr. Öğr. Gör., İstanbul Medeniyet Üniversitesi, İMÜ TÖMER (İstanbul,Türkiye). elif.ermagan@medeniyet.edu.tr, ORCID ID: 0000-0002-2827-0155. [Araştırma makalesi, Makale kayıt tarihi: 24.07.2021-kabul tarihi: 20.08.2021; DOI: 10.29000/rumelide.983856]

RumeliDE Dil ve Edebiyat Araştırmaları Dergisi Osmanağa Mahallesi, Mürver Çiçeği Sokak, No:14/8 Kadıköy - ISTANBUL / TÜRKIYE 34714 e-posta: editor@rumelide.com tel: +90 $5057958124,+902167730616$
Address

RumeliDE Journal of Language and Literature Studies Osmanağa Mahallesi, Mürver Çiçeği Sokak, No:14/8

Kadıköy - ISTANBUL / TURKEY 34714

e-mail: editor@rumelide.com

phone: +90 505 7958124, +90 2167730616 
Evaluation in terms of language teaching "Turkish: A Guide to the Spoken Language", a book written to teach Turkish to American soldiers during The II. World War / E. Ermağan (pp. 43-55)

collected through document analysis and the themes were determined by examining the obtained data with the content analysis technique. In the findings of the research in this book, which was written with the Audio-lingual method, it was determined that the pronunciation exercises for the development of speaking skills were focused on in accordance with the purpose, the vocabulary teaching was transferred in Turkish-English comparatively, and the word list planned to be taught was tried to be selected for the target audience.

Keywords: Speaking Skill, Audio-lingual Method, II. World War

\section{Giriş}

Ders kitapları, zamansız materyallerden olup gerek öğrenici gerekse öğretici tarafından her daim başvurulan kaynaklardan olmuştur ve bu durum günümüzde de geçerliliğini basılı kitap ya da teknolojinin gelişimiyle elektronik kitaba evrilen şekliyle de korumaktadır. Kalaycı ve Durukan'ın ifade ettiği gibi hedef dili farklı amaçlar için öğrenmek isteyen bireylerin başvuracağı ilk materyal ders kitaplarıdır (Kalaycı ve Durukan, 2019: 2164). Bazı ders kitapları aynı zamanda kendi kendine Türkçe öğrenimi amacına yönelik kullanılma özelliğine sahip olabildiği gibi öğretmen rehberli kullanıma özgü ders kitabından bağımsız, sadece kendi kendine Türkçe öğrenmeye yönelik hazırlanmış özel amaçlı dil öğretim kitapları da mevcuttur. Bununla beraber ders kitaplarıyla birlikte ek materyal olarak kullanılan kendi kendine Türkçe öğrenme kitapları da bulunmaktadır. Kendi kendine dil öğrenme kitapları, birçok noktada ders kitaplarından ayrılmaktadır. Özbal, çalışmasında kendi kendine öğrenme materyalleriyle ders kitaplarını karşılaştırarak kendi kendine dil öğrenme materyallerinin özelliklerini, ilgi çekici, öğrenen kullanımı için hazırlanan, tahmini çalışma süresine yer verilen, belirli bir hedef kitle için tasarlanan, amaç ve hedeflerin daima belirtildiği, çok farklı yolların kullanılabildiği kitaplar olarak belirlemektedir. Ayrıca, öz değerlendirmeye vurgu yapılan, olası öğrenme zorluklarına karşı uyarıların yapıldığı, özet bilgilere, öğrenme sürecine yönelik önerilere daima yer verilen, yalın içerik ve tasarıma sahip, etkili bir öğretimin hedeflendiği kitaplar olarak diğer özelliklerini tespit etmektedir (Özbal, 2020: 1606-1607).

Kendi kendine bir dili öğrenmeye yönelik hazırlanan kitapların özelliklerinden olan hedef kitleye yönelik tasarlanması maddesi daha da genişletilecek olursa, öğrenicinin yaşı, mesleği, ana dili, bildiği diller, gerçekleştirecekleri faaliyet (ör. Askerlikle ilgili), bir ülkeye geliş şekilleri (ör. Gönüllü göç ya da zorunlu göç) ya da öğrenicide geliştirilmek istenen beceriye yönelik hazırlanan kitaplar (ör. Konuşma kılavuzları) olmak üzere çeşitlenmektedir.

Genel amaçlı Türkçe öğretiminin dışında özel amaçlı Türkçe öğretiminin de hedeflendiği kendi kendine dil öğrenme kitapları bu noktada ders kitaplarından ayrılmaktadır. Demircan, özel amaçlı dil öğretiminin tanımını yaparak bir nevi genel amaçlı dil öğretiminden farkını ortaya çıkarmaktadır. Demircan, özel amaçlı dil öğretimini, sözel anlatım alanlarından sayılabilecek bilim, teknik, mesleğe özgü tercih edilen sözlük, yapı ve işlev ile ilgili dilin özelliklerinin meydana getirdiği iletişim aracı şeklinde tanımlamaktadır (Demircan, 2005: 261). Mackay’a (1978) göre, öğrencilerin özel ihtiyaçlarını karşılamayı ve öğrencilerin dilsel yeterliliklerini geliştirmeyi amaçlamaktadır. Ö ğrenme amaçları, ister bilimsel makaleleri okumak isterse bir petrol platformundaki teknisyenlerle iletişim kurmak olsun, dilin koyacağı bu özel amaçlar açısından tanımlanabilir (akt. Rao, 2019: 3). İmer, Kocaman ve Özsoy ise İngilizce üzerinden özel amaçlı dil öğretimini, “özel amaçlı İngilizce” maddesinde tanımlamaktadır. Genel bir yeterlik düzeyi amaçlayan İngilizce bilgisine karşıt olarak, amacı ve içeriği, belli bir öğrenci kesiminin (örn. Tıp, turizm, hukuk) gereksinmelerine ve dilin belli bir kesitine yönelik İngilizce türü olarak betimlemektedir. Ayrıca, özel amaçlı dil kullanımında

\footnotetext{
Adres

RumeliDE Dil ve Edebiyat Araştırmaları Dergisi Osmanağa Mahallesi, Mürver Çiçeği Sokak, No:14/8 Kadıköy - ISTANBUL / TÜRKIYE 34714 e-posta: editor@rumelide.com tel: +90 $5057958124,+902167730616$

RumeliDE Journal of Language and Literature Studies

Osmanağa Mahallesi, Mürver Çiçeği Sokak, No:14/8

Kadıköy - ISTANBUL / TURKEY 34714

e-mail: editor@rumelide.com,

phone: +90 5057958124 , +90 2167730616
} 
sözcükler, sözdizimi ve öteki dilsel özelliklerin genel dilden ayrım gösterdiğini ifade etmektedir (İmer, Kocaman ve Özsoy, 2013: 212).

Yukarıdaki tanımlardan da anlaşılacağı üzere, özel amaçlı dil öğretimi, genellikle belli bir alana özgü tercih edilen kelime varlığı ve bu kelime varlı̆̆ıyla oluşturulmuş dil bilgisel ve işlevsel dil kullanımının belirli beceri ya da becerileri kazandırmayı hedeflediği dil öğretimidir. Bu özel amaçlı dil öğretim kitapları arasında mesleğe yönelik kitaplara ayrıca parantez açmakta fayda olduğu düşünülmektedir. Lamri, özel amaçlı dil öğretim kitaplarının rolünün, dil öğrenenlerin onları belirli bir araştırma, meslek veya işyeri alanında kullanmak için gerekli yetenekleri geliştirmelerine yardımcı olduğu çıkarımına ulaşır (Lamri, 2016: 3). Lamri, burada meslekî amaçlı dil öğrenimini vurgulamıştır. Tarihten bu yana belli meslek grupları arasında ülkeler arası ilişkilerde önemli rolü olan askerî personele yönelik yazılmalarıyla öne çıkan iki dilli kitaplar bulunmaktadır. Bu kitaplardan, on dokuzuncu yüzyılda askerî personel için Redhouse ve Anton Tien tarafından yazılmış kitapların içeriğine yer verilmektedir.

Tuncer, Redhouse'un Kırım Harbi sırasında Osmanlı'yla ittifak eden İngilizlerin bu sefere katılacak İngiliz subayları için hazırladığı Türkçe gramer, meşhur diyaloglar ve İngilizce-Türkçe ve Türkçe-İngilizce sözlükten oluşan çalışması olduğunu ifade etmektedir. Ayrıca, ikinci olarak da 1857 tarihli Redhouse'un Kırım Harbi sırasında hazırlayıp bastırdığı söylenilen "iki kısımdan müteșekkil" sözlüğü olduğunu belirtmektedir (Tuncer, 2012: 50). Bir diğer kitap, Anton Tien tarafından 1896'da yayımlanan dil bilgisi kitabı niteliğindeki kitaptır. Kitabın ithaf bölümünde Tien, Eski Kırım günlerinin hatırasına eserini majestelerinin ordu ve donanma subaylarına sunduğunu belirtmiștir (Tien, 1896). Ayrıca Yeşilyurt da yaptığı çalışmasında Osmanlı döneminde kaleme alınmış Türkçeyi öğretmeye yönelik hazırlanmış kitaplarda hedef grubun gözetilerek, eserin bu gruba göre düzenlendiğini belirterek, Tien'in yukarıda tanımlanan eserine yer vermektedir (Yeşilyurt, 2016: 290).

Her ne kadar yukarıdaki örneklerde Osmanlı döneminde hedef kitleye yönelik yazılmış özel amaçlı ders kitapları kategorisinde değerlendirilebilecek kitaplar yazılsa da Strevens (1977) özel amaçlı dil öğretiminin asıl büyük gelişimini II. Dünya Savaşı yıllarında Britanya, ABD ve diğer devletlerin askerî mücadelelerinin artması ile ilişkilendirir. Bu dönemde askerî personelin kısa sürede ve amaca yönelik dil öğrenme ihtiyaçları ön plana çıkmıştır (akt. Kurt, 2020: 14). Starfield de Strevens'in görüşünü destekler nitelikte, bir dili genel amaçlardan ziyade özel amaçlar için öğrenmek ve öğretmenin, II. Dünya Savaşı'ndan sonra gelişmeye başladığını ve o zamandan beri hem teorik hem de metodolojik olarak gelişme gösteren bir yaklaşım olduğunu ifade etmektedir (Starfield, 2013: 1).

Özel amaçlı dil öğretimi, işitsel-dilsel yöntemin çıkışını da tetiklemiştir. Özel amaçlı dil öğretimini destekleyecek yöntemler, Memiş ve Erdem'in de belirttiği gibi ABD’nin II. Dünya Savaşı öncesinde 1930'lu yıllarda askeri üsler kurmasıyla gelişen ihtiyacı karşılamamış, üs kurdukları ülkelerin dilini öğrenmeyi bir nevi zorunlu ve ihtiyaç kılan askeri ilişkilerin gelişimi için işitsel-dilsel yöntem Michigan Üniversitesinin önderliğinde geliştirilmiştir (Memiş ve Erdem, 2013: 303).

Doğru da, İkinci Dünya Savaşı'na ABD’nin girmesiyle birlikte konuşma becerisini kısa sürede öğretmeyi hedefleyen işitsel-dilsel yönteme doğru giden süreci aktarmaktadır. Doğru, ABD’nin İkinci Dünya Savaşı'na girmesinin Amerika'daki dil öğretimini köklü bir şekilde etkilediğini, Amerikan hükümetinin, Almanca, Fransızca, İtalyanca, Çince, Japonca, Malayca ve diğer dilleri iyi derecede bilen raportör ve çevirmenlere duyduğu ihtiyacın özel bir eğitim programının geliştirilmesini zorunlu kıldığını ifade etmektedir. Bunun için askeri personele yabancı dil öğretmek üzere Amerikan üniversitelerinin görevlendirildiğini, 1942'de ordu özel programı (ASTP) kurulduğunu ve bu programa 1943 yılının sonlarında yaklaşık 45 üniversitenin

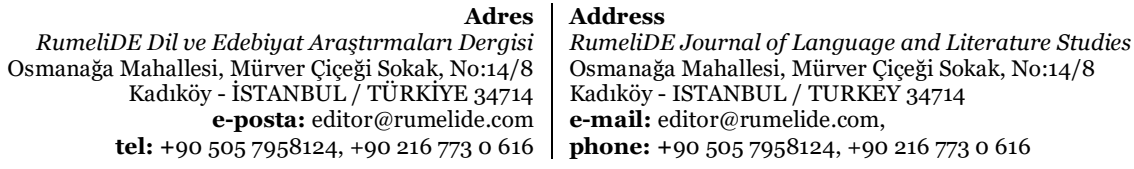


Evaluation in terms of language teaching "Turkish: A Guide to the Spoken Language", a book written to teach Turkish to American soldiers during The II. World War / E. Ermağan (pp. 43-55)

katıldığını belirtmekte ve ordu programlarının amacının da personele bir dizi yabancı dil konusunda konuşma becerisi kazandırmak olduğunu ortaya koymaktadır (Doğru, 2010: 120).

Doğru'nun da altını çizdiği gibi bu süreç daha sonra ordu yöntemi olarak da bilinen işitsel - dilsel yöntemi doğuracaktır. İkinci Dünya Savaşı sonrasında ise doğrudan ya da dolaylı olarak askerî personele yönelik özel amaçlı Türkçe öğretmeyi hedefleyen kitaplar yazılmaya devam etmiştir. Bunlardan biri, Geoffrey Lewis tarafından 1953'te yazılan Türkçe-İngilizce iki dilli bir kitaptır. Saraç, askerî personele yönelik yazılan bu kitabın yazımında NATO'ya Türkiye'nin girmesinin etken olduğunu ve bir yll sonra Turkish isimli eserin yayımlandığını ifade etmektedir. Ayrıca Saraç, eserin amacının genel anlamda bireysel olarak Türkçe öğrenmeye çalışanlara yönelik olarak nitelendirildiğini ancak ekler kısmında askeri personele yönelik yer verilen bölümlerden hareketle NATO için görev yapacak askeri personele ya da bu mesleğe ilgisi olanlara ithafen yazılmış olabileceğini belirtmektedir (Saraç, 2018: 47).

19.yüzyıldan 20. yüzylla değin askeri personele yönelik yazılmalarıyla öne çıkan Türkçe-İngilizce iki dilli kitapların özelliklerinden yola çıkılarak bu kitapların yazımında ülkeler arası askerî ilişkilerin etken olduğu, askerî personelin meslekî ve sosyal yaşamlarında iletişimlerine yardımcı olan, günlük hayattan örneklerin yer aldığı kitaplar olmaları sonucu çıkarılabilir.

Bu çalışmada da Amerikan askerlerine konuşma ağırlıklı Türkçe öğretmek için yazılan "Turkish: A Guide to the Spoken Language" adlı eser çeşitli açllardan incelenerek kitabın yönteminin bir nevi sağlaması yapılmıştır. Ünver, bir dil öğretimi metodunu belirlemenin yabancı dil öğretmeye yönelik oluşturulmuş ders kitaplarında bir açıdan iz sürme gibi olduğunu, konu alanı ders kitabı inceleme kriterlerden de sayılabilecek kitabın yazıldığı, kullanıldığı dönem, hedef kitlenin bilgisi, hangi metin türlerinin tercih edildiği, dil bilgisi, dilsel becerilerin etkisi ve nasıl verildiği, ülke bilgisi, kitapta kullanılan görseller, alıștırma türleri ve ek malzemeyi göz önünde bulundurup bir nevi kitabın önemini, nitelik ve niceliğini belirlemenin yöntem bilgisine giden yol olduğunu ifade etmektedir (Ünver, 2013: 191).

\section{Yöntem}

Nitel araștırma, verilerin kodlanıp temaların çıkarılması, bunların düzenlenmesi, bulguların tanımlanarak yorumlanması olmak üzere dört aşamada analiz edilir (Yıldırım ve Şimşek, 2016: 242-252). Bu çalışma da nitel bir araştırma olup çalışmanın veri kaynağı incelenerek veriler toplanmış ve analiz edilerek sonrasında bulgular yorumlanmıștır.

\section{Veri kaynağı}

Bu çalışmanın evrenini, kendi kendine Türkçe öğrenimini hedefleyen Türkçe-İngilizce iki dilli olarak yazılmış özel amaçlı dil öğretimi kitaplarının içeriği oluşturmaktadır. Araştırmanın veri kaynağını ise amaçlı örnekleme yöntemiyle örneklem olarak seçilen Turkish: A Guide To The Spoken Language adlı kitap oluşturmaktadır. Kendi kendine Türkçe öğrenme kategorisinde belirli bir meslek grubunda yer alan Amerikalı askerî personele yönelik yazılmasıyla özel amaçlı dil öğretimini hedefleyen bu kitap ABD'nin Savaş Bölümü tarafından 1943 yılında yayımlanmıştır.

\section{Verilerin toplanması ve analizi}

Araştırmanın verileri, nitel veri toplama yöntemlerinden olan doküman incelemesi aracıllğı̆yla toplanmıştır. Doküman incelemesi, araştırılması hedeflenen olgu veya olgular hakkında bilgi içeren yazılı ve görsel malzemelerin analizini kapsar (Yıldırım ve Şimşek, 2016: 189-190). Çalışmada doküman incelemesiyle elde

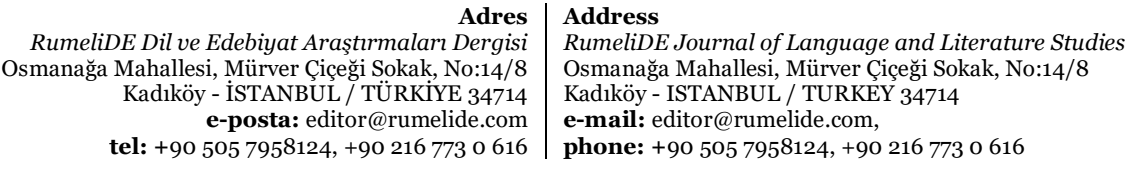


edilen veriler, içerik analizi tekniği kullanılarak değerlendirilmiştir. İçerik analizi, sözel, yazılı ve diğer materyallerin içerdiği mesajı, anlam ve/veya dil bilgisi açısından nesnel ve sistematik olarak sınıflandırma, sayılara dönüştürme ve çıkarımda bulunmadır (Tavşancıl ve Aslan, 2001: 22). İçerik analizinde temel amaç, toplanan verileri açılklayabilecek kavramlara ve ilişkilere ulaşmaktır (Yıldırım ve Şimşek, 2016: 242). Eser; yazılıș amacı, hedef kitle, eserin genel yapısı, dil öğretim yöntemi, dil bilgisi öğretimi, dil becerileri, kültür aktarımı, görseller ve alıştırmalar olmak üzere dokuz başlık altında analiz edilmiştir. Bu dokuz tema, veri kaynağından alınan yazılı ve görsel malzemelerle betimlenmiştir.

\section{Bulgular ve yorumlar}

Bu kitabın hedef kitlesi Amerikan askerleri olup kitap, hedef grubun basit konuşmalar yapmalarını hedeflemektedir. Eser, Türkçeye tam bir hâkimiyet kazandırmayı amaçlamamaktadır. Kapsamlı bir kurs için hedef gruba, ABD Silahlı Kuvvetler Enstitüsü, Madison, Wisconsin'e gitmeleri tavsiye edilmektedir. Bu el kitabının amacı hedef kitlenin dilde basit konuşmalar yapmalarını sağlamaktır.

Eser, cep kitap niteliğinde olup 80 sayfadır. Eserin içindekiler sayfasında eserde yer alan bölüm başlıkları şu şekilde sıralanmıştır: "How to Use the Records and Guide" (s. 5-7), "Hints on Pronunciation" (s. 7-9), "Special Points" (s. 9-12), "Useful Words and Phrases" (s. 12), "Greetings and General Phrases" (s. 12-15), "Location" (s. 15-16), "Directions" (s. 16-17), "Numbers" (s. 17-19), "What's This?" (s. 19), "Asking for Things" (s. 19-23), "Money" (s. 23-24), "Time" (s. 24), "Useful Phrases" (s. 27-28), "Additional Expressions" (s. 28-32), Fiil-in Sentence (s.32-46), "Important Signs" (s. 46-49), "Alphabetical Word List” (s. 49).

Kitabın içeriğinden, hedef kitle ve kitabın amacından da görüldüğü gibi kitabın günlük konuşma dilini kısa sürede öğretmeyi hedeflediği yöntem işitsel-dilsel yöntemdir. Kitapta bu yöntemi vurgulayan birden çok görsel öge tespit edilmiştir. İşitsel-dilsel yöntem, yabancı dil eğitiminde hazırlanan kalıp ifadelerin sürekli, tekrarla dinleme yoluyla kazandırılması ve anlatma becerilerinden konuşmayla pekiştirilmesi hedefi güden dinleme ve konuşma becerilerinin gelişimine ağırlık veren yabancı dil öğretim yöntemidir. Bu bağlamda işitsel-dilsel yöntemin Türkçeyi öğretmede nasıl kullanılacağını gösteren görsellerden bazıları şunlardır:

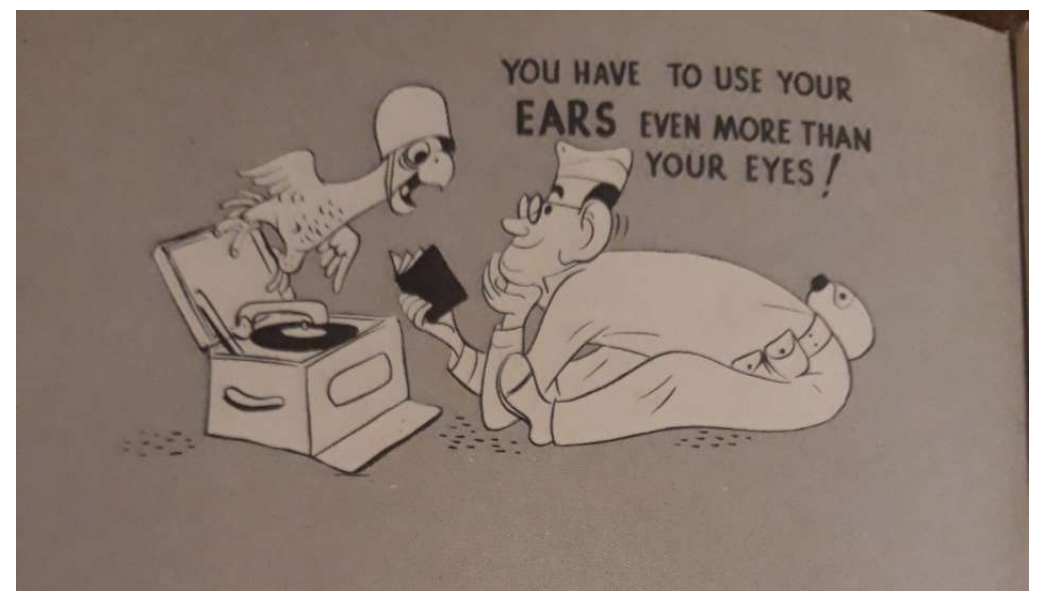

Şekil 1: Kitabın yöntemini gösteren görsel (s.6)

Şekil 1'de görüldügü gibi kayıttan dinlediğini tekrar eden bir askere papağan "gözlerinden daha çok kulaklarını kullanmalısın” diyerek işitsel-dilsel yöntemin duy-konuş özelliğine ve papağan görselinin kullanılması da bu yöntemde tekrarın önemine vurgu yapmaktadır.

\footnotetext{
RumeliDE Dil ve Edebiyat Araştırmaları Dergisi RumeliDE Dil ve Edebiyat Araştırmaları Dergisi
Osmanağa Mahallesi, Mürver Ciçeği Sokak, No:14/8 Kadıköy - ÍSTANBUL / TÜRKIYE 34714 e-posta: editor@rumelide.com tel: +90 505 7958124, +902167730616

Address

RumeliDE Journal of Language and Literature Studies Osmanağa Mahallesi, Mürver Çiçeği Sokak, No:14/8

Kadıköy - ISTANBUL / TURKEY 34714

e-mail: editor@rumelide.com,

phone: +90 505 7958124, +90 2167730616
} 
Evaluation in terms of language teaching "Turkish: A Guide to the Spoken Language", a book written to teach Turkish to American soldiers during The II. World War / E. Ermağan (pp. 43-55)

Kitapta konuşma becerisinin kazandırılmasıyla ilgili olarak telaffuz öğretimine ait "Hints on Pronunciation" (Telaffuzla İlgili İpuçları) adıyla bir bölüm bulunmakla birlikte telaffuzla ilgili ilk kısımda genel nitelikte tavsiyeler bulunmaktadır. Öğrenicilere "Telaffuzla İlgili İpuçları” adıı bölümü okuyup, yararlı sözcükler ve deyimleri ezbere öğrenene kadar kayıttan dinlemelerini, her kelimeyi duyduktan hemen sonra yüksek sesle tekrarlamalarını ve Türkçeyi konuşanların yaptığı gibi söylemelerini, öğrenicilerin olağandışı bir aksanı olan birini taklit edebilecekleri gibi telaffuzu olabildiğince yakından taklit etmelerini, telaffuzun her detayını, hatta ritim ve tonlamayı bile almaya çalışmayı, yazılanlardan farklı bir şey duyduklarında rehberlerindeki kelimeleri takip etmelerini, ancak bunları yalnızca bir hatırlatma olarak kullanmalarını belirtmektedir. Kitap ayrıca, bir dilin sesinin yalnızca basılı sözcükten alınamayacağını kulakların gözlerden daha fazla kullanılmasını gerektiğini, bunun dışında, öğrenicilerin yanında kayıtları yoksa ve kelimeleri Türkçe konuşan birine okutamıyorlarsa yalnızca telaffuzla ilgili ipuçlarına güvenmeleri gerektiğini öğütlemektedir. (War Department, 1943: 6-7).

Telaffuzun önemini gösteren görsellere kitaptan alıntı yapılarak yer verilmiştir (bkz. Şekil 2; 3; 4; 5).

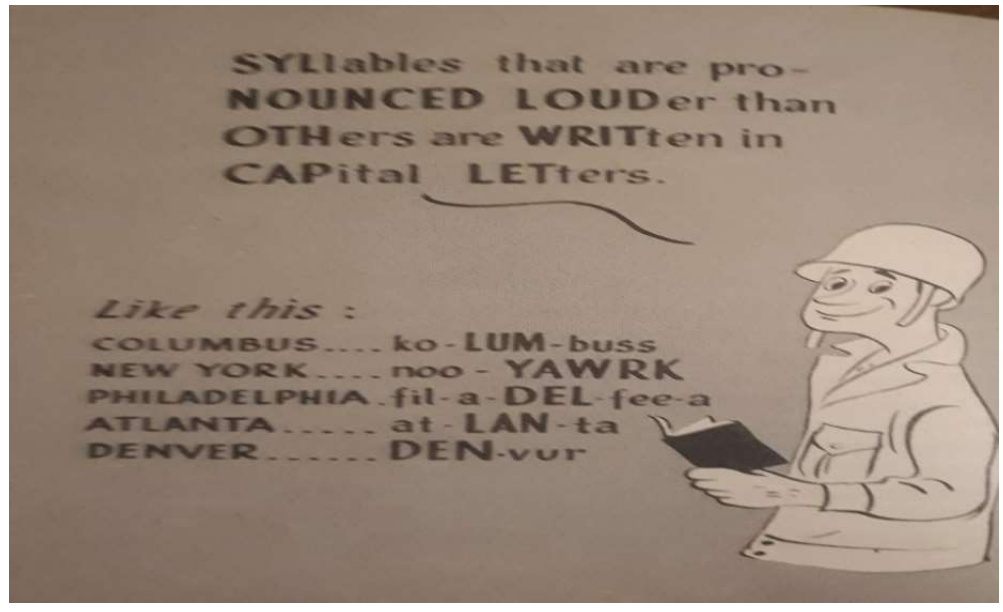

Şekil 2: Telaffuzda vurgunun önemini gösteren görsel (s.8)

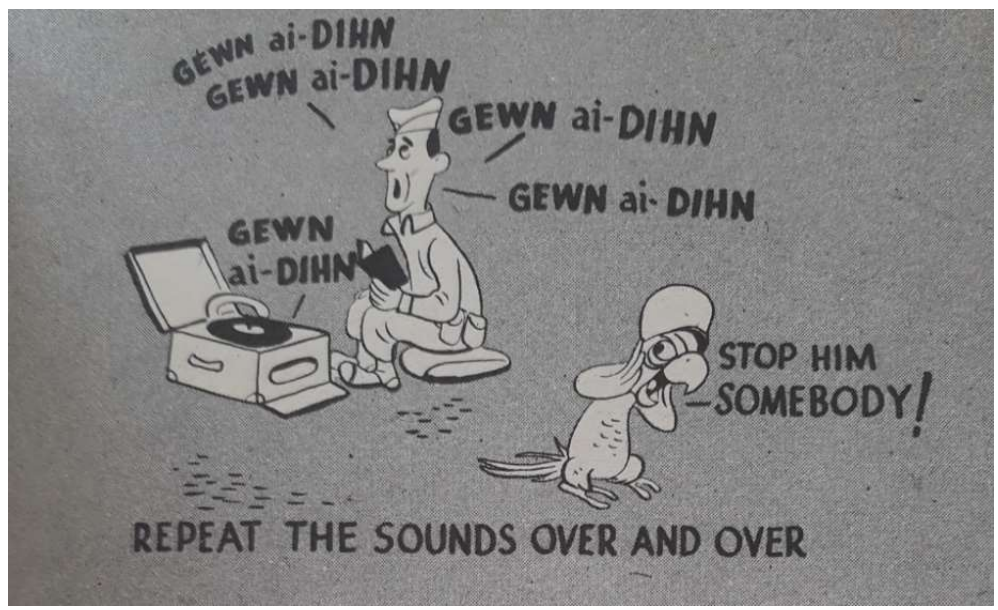

Şekil 3: Telaffuzda tekrarın önemini gösteren görsel (s.13)

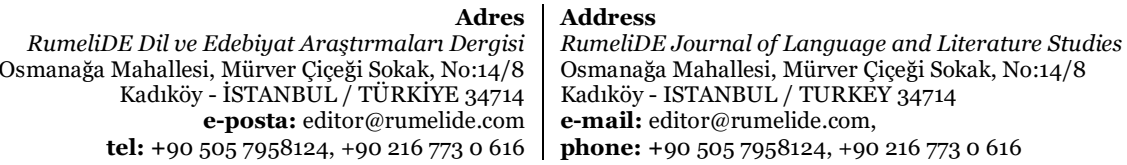




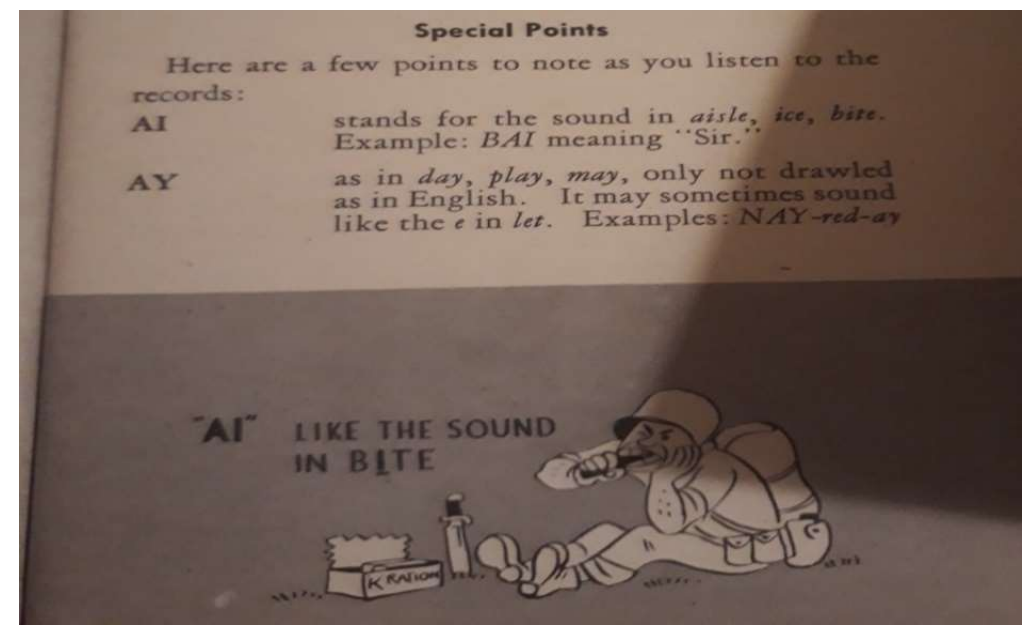

Şekil 4: Kaynak ve hedef dildeki ses benzerliğinden yola çıkılarak telaffuzda kolaylık sağlamayı hedefleyen bir görsel (s.9)

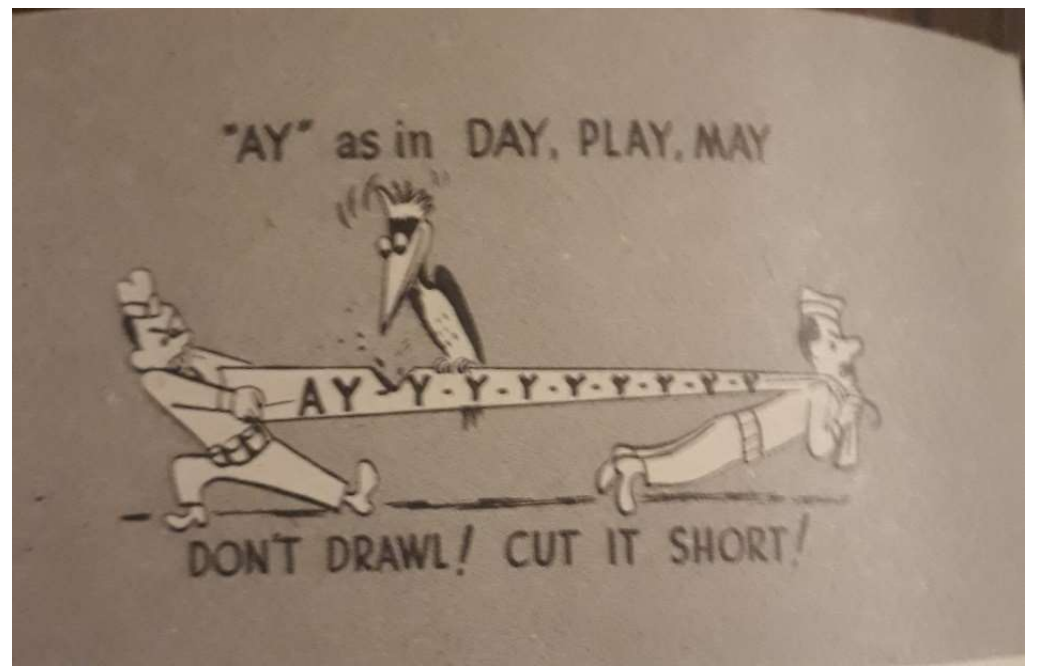

Şekil 5: Telaffuzda hecelerin uzunluk kısalığına vurgu yapan bir görsel (s.11)

Görsellerin tamamına bakıldığında, telaffuz öğretiminde öğrenicinin ana dilinden hareketle telaffuz ipuçları verildiği, hecelerin uzunluk, kısalıklarına ve vurguya dikkat çekildiği ve iyi bir telaffuz için tekrarın önemini ortaya koyan görsellerin yoğun olarak yer aldığı görülmektedir.

İşitsel-dilsel yöntemde dil bilgisi ise doğrudan değil, dil bilgisel açıklamalara yer verilmeksizin cümle veya dil bilgisi yapılarının yer aldığı kelimelerle doğrudan öğretilir. İncelenen kitapta da dil bilgisinin öğretilmesi anahtar dil bilgisel kalıpların bilinmesine ve bu kalıplarla kullanılacak yeterli sayıda kelimenin öğrenilmesine bağlıdır. Bu nedenle kitapta verilmiş sözcük listesinden herhangi biri ile doldurulabilecek bir boşluk içeren cümlelere etkinliklerde yer verilmiştir.

Ayrıca kitapta söz dizimine de dikkat çekilerek Türkçedeki kelimelerin sırasının İngilizcedekinden farklı olduğu belirtilerek bu durum örneklendirilmiştir.

RumeliDE Dil ve Edebiyat Araşturmaları Dergisi Osmanağa Mahallesi, Mürver Çiçeği Sokak, No:14/8 Kadıköy - ISTANBUL / TÜRKIYE 34714 e-posta: editor@rumelide.com tel: +90 $5057958124,+902167730616$
Address

RumeliDE Journal of Language and Literature Studies

Osmanağa Mahallesi, Mürver Çiçeği Sokak, No:14/8

Kadıköy - ISTANBUL / TURKEY 34714

e-mail: editor@rumelide.com,

phone: +90 5057958124, +90 2167730616 
Evaluation in terms of language teaching "Turkish: A Guide to the Spoken Language", a book written to teach Turkish to American soldiers during The II. World War / E. Ermağan (pp. 43-55)

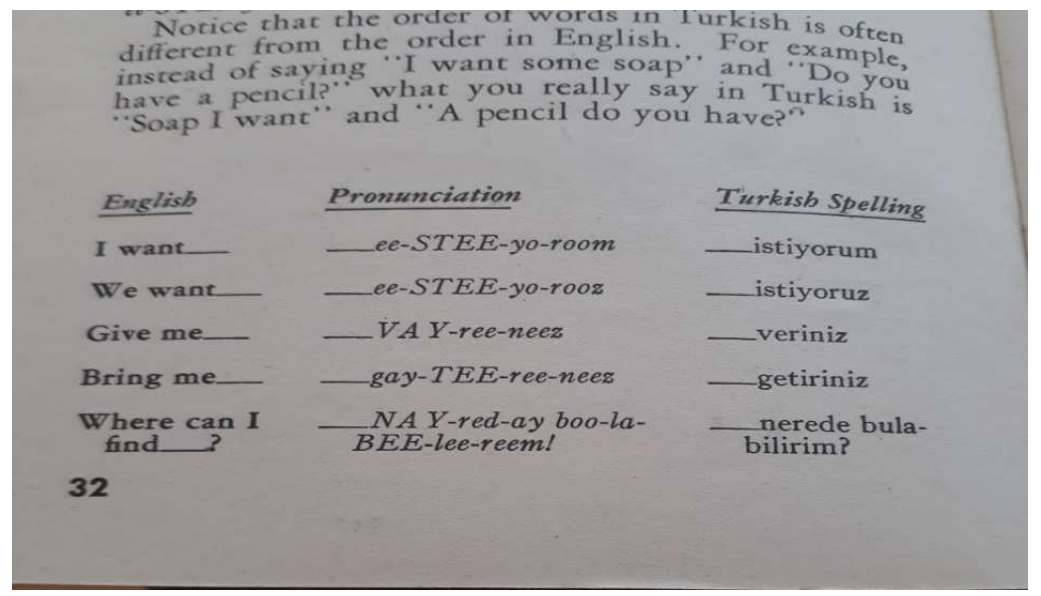

Şekil 6: Söz dizimine ilişkin açıklama ve kalıp cümlelerin öğretimiyle ilgili görsel (s.32)

Şekil 6'da da görüldüğü gibi, dil bilgisel açıklamalar olmaksızın kalıp ifadeler çevirileriyle birlikte iki dil arasındaki kelime sıralamasını dolayısıyla yapısal farklılığı da vurgulayacak şekilde hem açıklamayla hem de örneklendirilerek verilmiştir.

Dil bilgisinin kavranmasıyla ilgili kitapta verilen alıștırmaların dışında yer alan alıştırmalara bakıldığında öğrenicinin kelime bilgisini ölçmeye yönelik yer alan alıştırmaların yanında, hedef dilde saati söyleme alıştırmalarının da olduğu tespit edilmiştir.

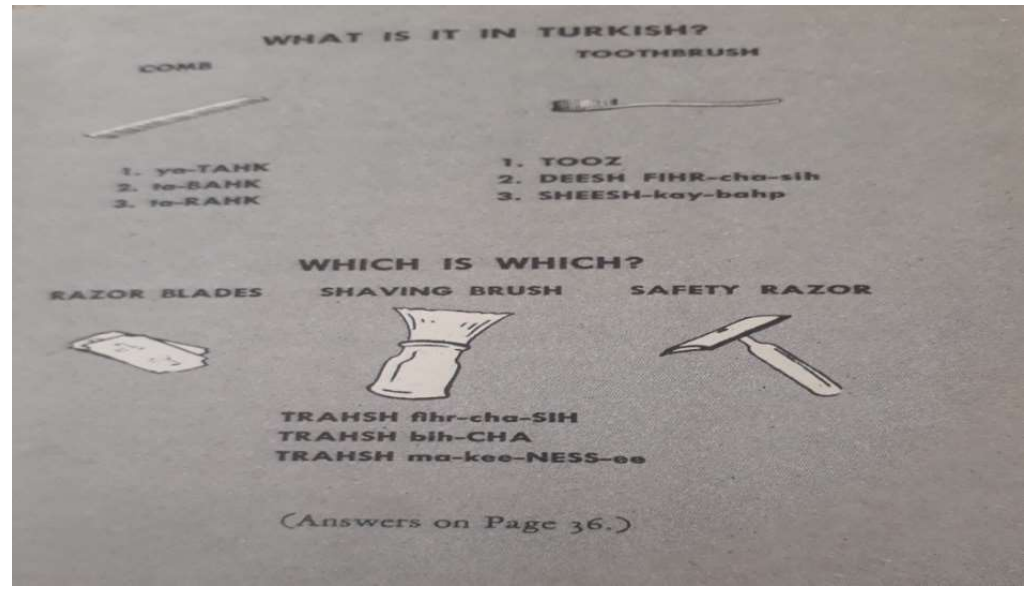

Şekil 7: Kelime bilgisini ölçmeye yönelik alıştırma (s.37)

RumeliDE Dil ve Edebiyat Araştırmaları Dergisi Osmanağa Mahallesi, Mürver Çiçeği Sokak, No:14/8 Kadıköy - ISTANBUL / TÜRKIYE 34714 e-posta: editor@rumelide.com tel: +90 $5057958124,+902167730616$
Address

RumeliDE Journal of Language and Literature Studies Osmanağa Mahallesi, Mürver Çiçeği Sokak, No:14/8

Kadıköy - ISTANBUL / TURKEY 34714

e-mail: editor@rumelide.com

phone: +90 505 7958124, +90 2167730616 


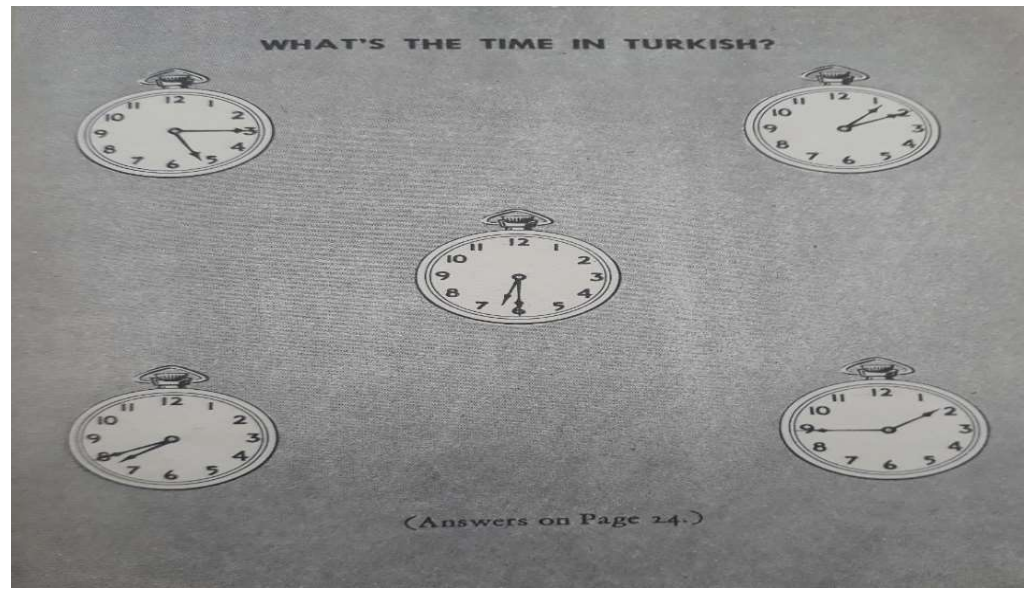

Şekil 8: Hedef dilde saati söyleme alıștırmaları (s.25)

Şekil 7'deki alıştırmada İngilizcesi verilen nesnelerin Türkçe karşılıkları seçenek sunularak sorulurken, bir diğer alıştırma eşleştirme alıştırmasıdır. Öğrenicilerin verdikleri cevaplarını kendilerinin ölçmesi için cevapların yer aldığı sayfa numarası da alıştırmaların altında yer almıştır. Şekil 8'de ise günlük dilde önemli bir yer tutan saati söyleme alıştırmalarına ve aynı şekilde cevaplarına yer verilmiştir.

Bu kitabın yöntemine uygun olarak konuşma becerisinin gelişimini destekleyen ve kitapta geniş yer verilen telaffuz öğretiminde tekrar alıştırmalarıyla birlikte hedef kültür aktarımının da konuşma becerisini nasıl desteklediği incelenmelidir. Kitaptaki hedef kültür aktarımına bakıldığında bunun hem söz varlığıyla hem de seçilen görsellerle sağlanmaya çalışıldığı tespit edilmiştir. Özel amaçlı kitaplar arasında yer alan bu kitapta hangi ögelerin seçileceği, günlük dilden nelerin hedef kültür aktarımı bağlamında ön plana çıkarılacağı önemlidir. Yabancı dil derslerinde kültür aktarımı yapılırken nelerin öğretileceğinin, hangi konuların öne çıkarılacağının belirlenmesi büyük önem taşımaktadır. İlgi çekici ve motive edici olma, kitabın amacıyla ve hedef kitleyle örtüşme, dilin daha iyi öğrenilmesine katkıda bulunma hedef kültür aktarımında dikkat edilmesi gerekenlerdendir.

Bu bağlamda değerlendirmeye tabi tutulacak hedef kültür aktarımıyla ilgili görseller aşağıda verilmiştir.

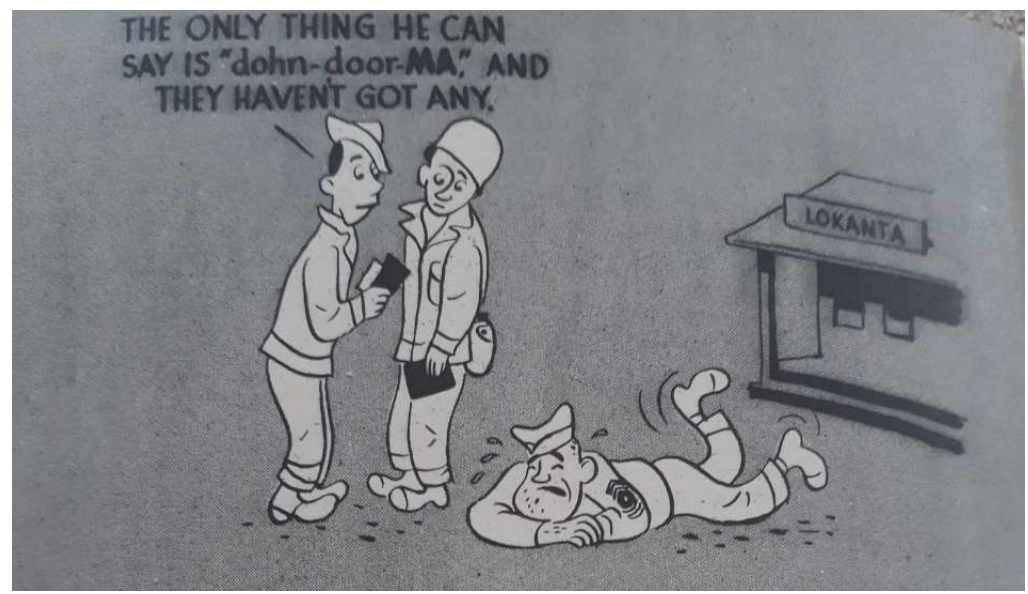

Şekil 9: Lokanta ve lokantada dondurma satılmadığını gösteren bir görsel

\begin{tabular}{r|l} 
Adres & Address \\
RumeliDE Dil ve Edebiyat Araştırmaları Dergisi & RumeliDE Journal of Language and Literature Studies \\
Osmanağa Mahallesi, Mürver Çiçeği Sokak, No:14/8 & Osmanağa Mahallesi, Mürver Çiçeği Sokak, No:14/8 \\
Kadıköy - İSTANBUL / TÜRKIYE 34714 & Kadıköy - ISTANBUL / TURKEY 34714 \\
e-posta: editor@rumelide.com & $\begin{array}{l}\text { e-mail: editor@rumelide.com, } \\
\text { phone: +90 505 7958124, +90 } 2167730616\end{array}$
\end{tabular}


Evaluation in terms of language teaching "Turkish: A Guide to the Spoken Language", a book written to teach Turkish to American soldiers during The II. World War / E. Ermağan (pp. 43-55)

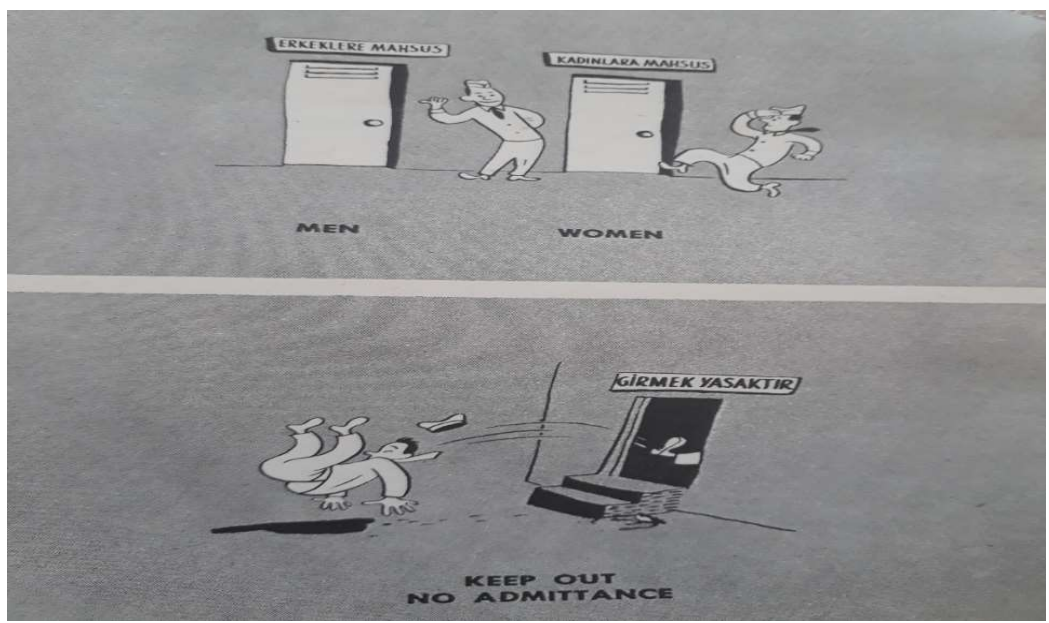

Şekil 10: Tuvalet kullanımında kadın ve erkek ayrımına dikkat çeken görsel

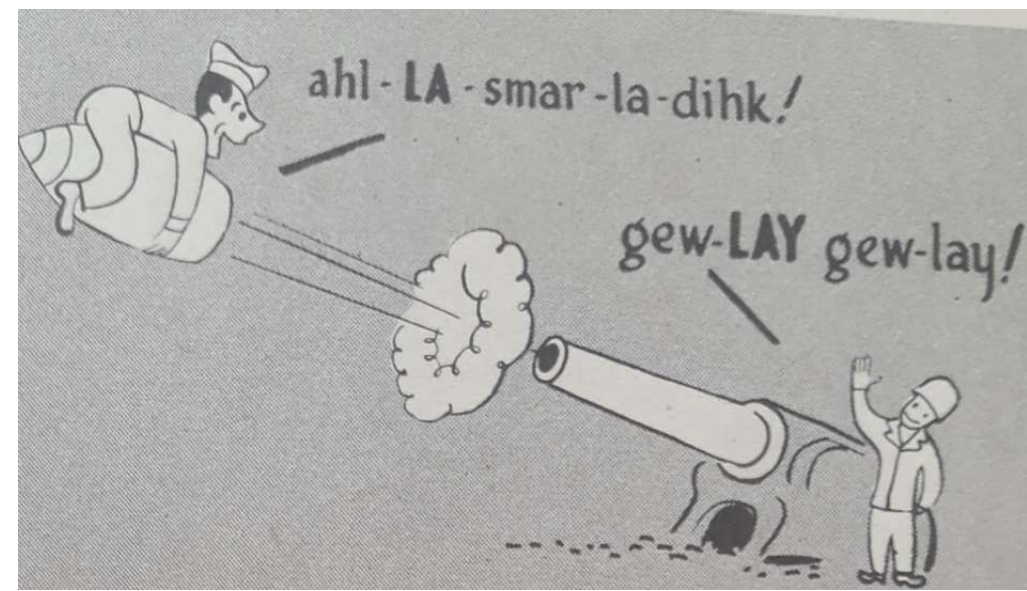

Şekil 11: Hedef kültüre ait uğurlama kalıplarına dikkat çeken görsel

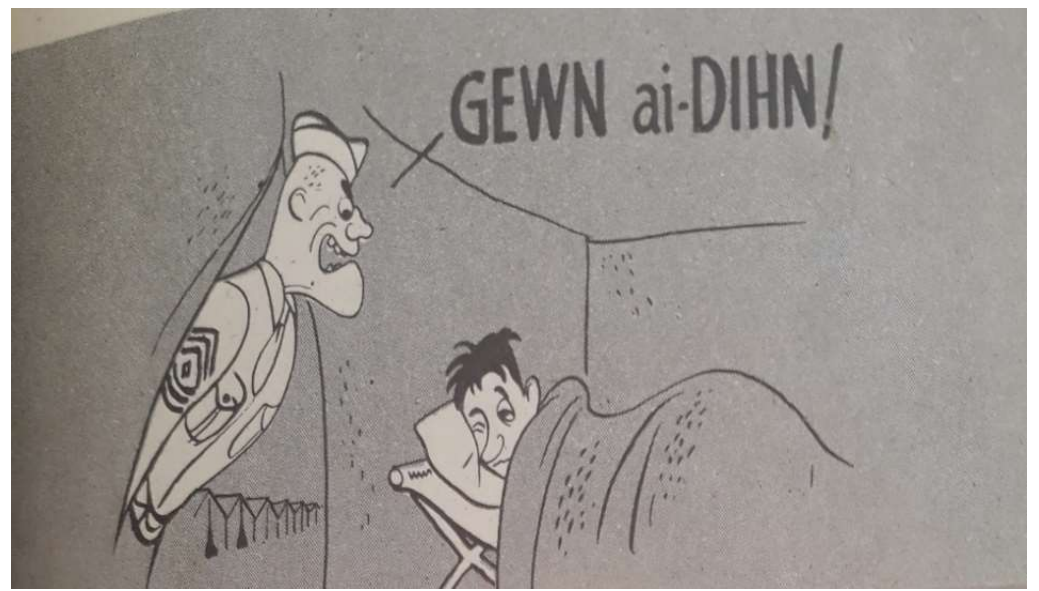

Şekil 12: Hedef kültüre ait selamlaşma kalıbına dikkat çeken bir görsel

\begin{tabular}{|c|c|}
\hline & \\
\hline e Edebiuat As & d Literatu \\
\hline a Mal & Mahallesi, Mürver Çiçe \\
\hline Kadıköy & STANBUL / TURKEY 34714 \\
\hline $\begin{array}{r}\text { e-posta: editor@rumelide.com } \\
\text { tel: +90 505 7958124, +90 } 2167730616\end{array}$ & $\begin{array}{l}\text { e-mail: editor@rumelide.com, } \\
\text { phone: +90 505 7958124, +90 } 2167730616\end{array}$ \\
\hline
\end{tabular}


Şekil 9 ve 10'da yer alan görsellerde günlük ihtiyaçlardan yola çıkılarak lokanta ve tuvalet kullanımında göz önünde bulundurulması gereken durumlara dikkat çekilmiștir. Ayrıca, bu görsel ögelerde dikkat çeken bir diğer nokta da, Brooks'ün (1986) Kültürel Ögelerle İlgili Sinıflandırma tablosunda geçen maddelerden biri olan hedef dili öğrenirken yapılan hatalar ve bu hataların hedef dilde yaratacağı etkilerdir (akt. Tüm ve Sarkmaz, 2012: 456). Görsellerde askerlerin hedef dili ve kültürünü öğrenirken muhtemel yapabileceği hatalar her iki kültür arasındaki farklılığa işaret edilerek Şekil 9 ve 10'da gösterilmiştir. Şekil 11 ve 12'de yer alan görsellerde ise selamlaşma ve uğurlama kalıplarına dikkat çekilmiştir.

Görsellerle birlikte hedef kültür aktarımında rol oynayan bir diğer öge de söz varlı̆̆ıdır. Söz varlı̆̆ı hedef kültür aktarımı açısından incelendiğinde selamlaşma ve genel ifadeler bölümünde günaydın, tünaydın, affedersiniz, teşekkür ederim kelimeleri (s.12); Mekân başlığına bakıldığında lokanta ve abdesthane kelimeleri dikkat çekmektedir (s.15) Bir şey sorma ilgili kelime listesine bakıldığında ise hurma ve şişkebap kelimeleri görülür. (s.21) Para ile ilgili bölüm incelendiğinde ise kuruş ve lira kelimeleri (s.23) Gerekli Kalıp Ifadeler kısmında ise Allahaısmarladık ve Güle güle dikkat çekmektedir (s.27).

Özetle denilebilir ki, kitabın başlığında konuşma kılavuzu olarak tanımlanan kitap, içerik analizinde çeşitli açllardan incelenerek başlıkla örtüşür sonuçlara ulaşılmıştır. Genç'in, Eğitim Sözlüğünde yer verdiği konuşma kılavuzu tanımı incelendiğinde, "bir dile ait kısa dil bilgisi açıklamalarının, konuşma kalıplarının ve sözcüklerin vb. yer aldığı el kitabı” tanımı karşımıza çıkmaktadır. Bu yönüyle eser bu tanımla da örtüşmektedir (Genç, 2012: 255).

\section{Sonuç}

Bu çalışmada 1943 basımlı ABD’nin Savaş Bölümü'nün hazırladı̆̆ı, Amerikan askerlerine Türkçe öğretmek için yazılan "Turkish: A Guide to the Spoken Language" adlı eser incelenerek şu sonuçlara ulaşılmıştır:

Eser, işitsel-dilsel yöntemin bir diğer adıyla ordu yönteminin kullanıldığı II. Dünya Savaşı'nın önemli aktörlerinden ABD'nin izlediği dil politikasına yönelik, doğrudan oluşturulmuş bir eserdir. Bu nedenle hedef grup olan askerlere yönelik bir içerik oluşturulduğu tespit edilmiştir. İçeriğin oluşturulmasında gerek söz varlığının gerekse görsellerin askerlerin ihtiyaçları gözetilerek ihtiyaç analizi sonucunda oluşturulduğunu söylemek mümkündür.

Eserin, işitsel-dilsel yönteme uygun olarak konuşma becerisine yoğunlaştığı saptanmıştır. Konuşma kılavuzu niteliğinde tanımlanabilecek eserde hedef dile ait telaffuz ipuçlarının gerek yazılı açıklamalarla gerekse görseller yoluyla verilmesi eserin konuşma becerisine yoğunlaştığının kanıtı olarak görülebilir.

Eserin söz varlığı incelendiğinde, askerî personele yönelik hazırlanmasından kaynaklı askerî terminolojiye çok ayrıntılı olmamak kaydıyla yer verildiği ayrıca hedef kültürün dikkate alınarak daha çok gündelik hayata ait söz varlığının oluşturulduğu tespit edilmiştir. Kitapta kullanılan söz varlığına bakıldığında günümüzde kullanılan kelimelerle örtüştüğü, yazıldığı döneme ait söz varlığının kitaba yansımadığı saptanmıştır.

Eserde yer alan görseller incelendiğinde, kitabın alıştırmalarında yer alan görseller dışında kalan tüm görsellerde askerî personeli gösteren çizimlerin yer aldığı belirlenmiștir. Görsellerin büyük çoğunluğunda askerî personel hareket halinde resmedilmiştir. Konuşma pratikleri yapan askerî personelin sesleri çıkarırken ağzının alacağı șekiller ya da sesleri yanlış çıkardığında karşısındaki kişiden aldığı uyarı sonucu yüzünün aldığı şekil ya da konuşmasını kontrol eden kişinin yüzünün aldığı ifade ayrıntılı tasvir edilerek görsellerle telaffuzun önemi vurgulanmıştır. Bunun dışında askerî personele ait görsellerle birlikte askerî

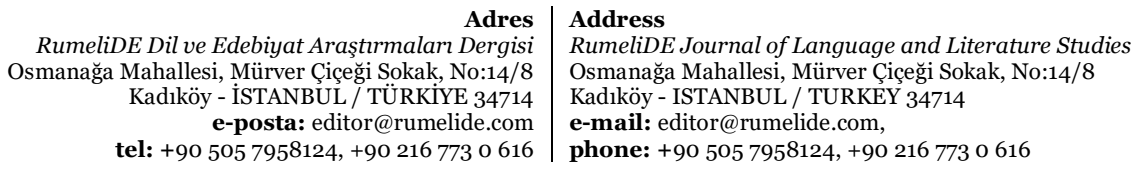


Evaluation in terms of language teaching "Turkish: A Guide to the Spoken Language", a book written to teach Turkish to American soldiers during The II. World War / E. Ermağan (pp. 43-55)

personelin kullandığı araçlar, askerî mühimmat gibi görsellere yer verilmiştir. Görsellerde dikkat çeken bir diğer unsur da, askerî personelin yaşayabileceği tehlikeli durumlara dayanarak oluşturulmuş uyarı niteliğindeki görsellerdir. Tüm bu durumlar göz önünde bulundurulduğunda kitabın, özel amaçlı dil öğretim kitaplarından olan belli bir mesleğe yönelik oluşturulan kitaplar kategorisinde değerlendirilebileceğini gösteren kriterlerden sayılabilecek görsellerin işleniş şekillerinin, kitabın amacıyla ve niteliğiyle örtüştüğü söylenebilir.

Eser cep kitap niteliğinde olduğu için, hedef kültür aktarımı, söz varlığı ve görseller aracıllğıyla sağlanmaya çalışılsa da kitabın hacmine ve yazılış amacına bağlı olarak sınırlı tutulduğu ancak özellikle görsellerde hedef kitle olan askerlerin dikkate alındığı tespit edilmiştir.

Dil bilgisi açıklamaları kısaca İngilizce yapılmış olup sadece kelime ve cümlelerin öğretiminde Türkçeİngilizce karşılaştırmalı bir yöntem tercih edilmiştir. Dil bilgisi açıklamalarının detaylı olmamasının sebebi ise daha önce belirtildiği gibi kitabın konuşma kılavuzu niteliğinde olması ve kazandırılmak istenen konuşma becerisinde dil bilgisinin ön planda olmamasıdır.

Veri kaynağı olarak incelenen eser, dilde basit konuşmalar yapmayı amaçladığı ve o dönemde askerî personelin ihtiyacını bu açıdan kısa sürede karşılamayı hedeflediği için içerik analizi sonucu amacına uygun olarak oluşturulduğu sonucu çıkarılmıştır.

Bu eser Türk-Amerikan ilişkilerini gösteren tarihî bir eser niteliğinden çok Amerikan askerlerinin kendi kendine Türkçe öğrenmelerini sağlayan özel amaçlı bir konuşma kılavuzu niteliğini taşımaktadır.

\section{Kaynakça}

Demircan, Ö. (2005). Yabancı dil öğretim yöntemleri. İstanbul: Der.

Doğru, E. (2010). İşitsel-dilsel yöntem. Eskiyeni, 119-127.

Genç, A. (2012). Eğitim sözlüğü (2. bs.). Ankara: Hacettepe.

İmer, K., Kocaman, A. ve Özsoy, A.S. (2013). Dilbilim sözlüğ̈̈ (2.bs.). İstanbul: Boğaziçi Üniversitesi.

Kalaycı, D. ve Durukan, E. (2019). Yabancı dil olarak Türkçe ve İngilizce öğretimi ders kitaplarının öğrenme alanları bakımından karşılaş̧ııılması. Uluslararası Türkçe Edebiyat Kültür Eğitim Dergisi, 8(4), 2162-2177. doi:http://dx.doi.org/10.7884/teke.4330

Kurt, V.(2020). Yabancllar için özel amaçl Türkçe öğretimi iş Türkçesi. Adana: Karahan Kitabevi.

Lamri, C. E. (2016). An introduction to English for specific purposes (ESP). (Yayımlanmamış ders notu). Abou Bekr Belkaid University Tlemcen Faculty or Arts and Languages Department of English, Chetouane. Erişim: https://faclettre.univtlemcen.dz/assets/uploads/DOCUMENTS/cours\%20en\%2oligne/4An\%20Introduction\%20to\%20ESP\%20LAMRI.pdf adresinden ulaşıldı.

Memiş, R. M. ve Erdem D. M. (2013). Yabancı dil öğretimde kullanılan yöntemler, kullanım özellikleri ve eleştiriler. Turkish Studies, 8(9), 297 - 318.

Özbal, B. (2020). Kendi kendine yabancı dil olarak Türkçe öğrenimi ders kitapları. Uluslararası Türkçe Edebiyat Kültür Ĕ̆itim Dergisi, 9(4), 602-1615.

Rao, V. C. S. (2019). English for business purposes: An ESP approach. Journal of Research Scholars and Professionals of English Language Teaching, 15(3), 1-8.

Saraç, Ş. (2018). Türkçenin yabancı dil olarak öğretimine İngiliz katkısı; Yayımlanmamış doktora tezi, Hacettepe Üniversitesi, Ankara.

Strevens, P. (1977). Special purpose language learning: A perspective. Language Teaching and Linguistic, 10, s. 145-163.

RumeliDE Dil ve Edebiyat Araştırmaları Dergisi Osmanağa Mahallesi, Mürver Çiçeği Sokak, No:14/8 Kadıköy - ISTANBUL / TÜRKIYE 34714 e-posta: editor@rumelide.com tel: +90 $5057958124,+902167730616$
Address

RumeliDE Journal of Language and Literature Studies

Osmanağa Mahallesi, Mürver Çiçeği Sokak, No:14/8

Kadıköy - ISTANBUL / TURKEY 34714

e-mail: editor@rumelide.com,

phone: +90 $5057958124,+902167730616$ 
II. Dünya Savaşı esnasında Amerikan askerlerine Türkçe öğretmek için yazılan "Turkish: A Guide To The Spoken Language” adlı kitabın dil öğretimi açısından değerlendirilmesi / E. Ermağan (43-55. s.)

Starfield, S. (2013). Historical development of language for specific purposes. Carol A. Chapelle (ed.), Encyclopedia of Applied Linguistics içinde (ss.1-6). Blackwell Publishing Ltd.

Tavşancıl, E. ve Aslan, E. (2001). Sözel, yazıl ve diğer materyaller için içerik analizi ve uygulama örnekleri. İstanbul: Epsilon.

Tien, A. (1896). A Turkish grammar, containing also dialogues and terms connected with the army, navy, military drill, diplomatic and social life. London: Sampson Low, Martson-Company. https://ia801805.us.archive.org/5/items/dli.ministry.24217/E06879_A_Turkish_Grammar.pd $\mathrm{f}$ adresinden 24.7.2021 tarihinde erişildi.

Tuncer, H. (2012). Doğu ile batı arasında bir köprü James William Redhouse, Yayımlanmamış yüksek lisans tezi, Mimar Sinan Güzel Sanatlar Üniversitesi, İstanbul.

Tüm, G. ve Sarkmaz, Ö. (2012). Yabancı dil Türkçe ders kitaplarında kültürel ögelerin yeri. Hacettepe Üniversitesi Eğitim Fakültesi Dergisi, 43(43), 448-459.

Ünver, S.. (2013). Alman askerlerine Türkçeyi öğretme ve Türkiye'yi tanıtma amacıyla yazılan bir kitabın incelenmesi. Milli Folklor, 25(100), 189-201.

War Department (1943). Turkish: A guide to the spoken language. Washington.

Yeşilyurt, E. (2016). Osmanlı döneminde İngilizlere Türkçe öğretmek amacıyla yazılan kitapların dil öğretimi açısından değerlendirilmesi. Ana Dili Ĕ̆itimi Dergisi, 4(3), 277-294.

Yıldırım, A. ve Şimşek, H. (2016). Sosyal bilimlerde nitel araştırma yöntemleri (10. bs.). Ankara: Seçkin.

RumeliDE Dil ve Edebiyat Araştırmaları Dergisi Osmanağa Mahallesi, Mürver Çiçeği Sokak, No:14/8 Kadıköy - İSTANBUL / TÜRKIYE 34714 e-posta: editor@rumelide.com tel: +90 $5057958124,+902167730616$
Address

RumeliDE Journal of Language and Literature Studies Osmanağa Mahallesi, Mürver Çiçeği Sokak, No:14/8

Kadıköy - ISTANBUL / TURKEY 34714

e-mail: editor@rumelide.com,

phone: +90 505 7958124, +90 2167730616 